\title{
Age norms for monocular grating acuity measured by sweep-VEP in the first three years of age
}

\author{
Estudo normativo de acuidade visual de resolução de grades medido pelo PVE \\ de varredura nos três primeiros anos de vida
}

\author{
Solange Rios Salomão ${ }^{1}$ \\ Fabio Ejzenbaum ${ }^{2}$ \\ Adriana Berezovsky ${ }^{3}$ \\ Paula Yuri Sacai $^{4}$ \\ Josenilson Martins Pereira ${ }^{5}$
}

\begin{tabular}{|l|}
\hline ABSTRACT \\
\hline Purpose: To determine age norms for grating visual acuity and interocular \\
acuity differences measured by the sweep-visually evoked potentials \\
(VEP) technique in the first three years of life. Methods: Monocular \\
grating visual acuity was measured using the sweep-VEP in 67 healthy \\
normal infants and children in the first 36 months of life. Results: Sweep- \\
VEP grating acuity ranged from $0.80 \log$ MAR ( $20 / 125$ Snellen equivalent) \\
in the first month of life to $0.06 \log$ MAR (20/20 Snellen equivalent) at 36 \\
months of age. Lower normal limits $\left(95^{\text {th }}\right.$ percentile limit) ranged from \\
0.95 logMAR (20/180) to 0.12 logMAR (20/25) with a progression of \\
approximately 3 octaves in the first 36 months of age. The largest ac- \\
ceptable interocular acuity difference for clinical purposes was 0.10 \\
logMAR. Conclusions: Age norms for grating acuity along with inte- \\
rocular acuity differences were determined using the sweep-VEP te- \\
chnique. These norms should be incorporated in clinical practice for \\
precise diagnosis of visual status in infants and preverbal children. \\
\hline
\end{tabular}

Keywords: Evoked potentials, visual; Visual acuity; Vision tests/standards; Predictive value of tests; Reference values
Trabalho realizado na Universidade Federal de São Paulo - UNIFESP.

${ }^{1}$ Professora associada do Departamento de Oftalmologia e chefe do Laboratório de Eletrofisiologia Visual Clínica do Departamento de Oftalmologia da Universidade Federal de São Paulo - UNIFESP - São Paulo (SP) Brasil.

2 Doutor em Oftalmologia pela UNIFESP - São Paulo (SP), Brasil.

${ }^{3}$ Professora Adjunta do Departamento de Oftalmologia da UNIFESP - São Paulo (SP) - Brasil.

${ }^{4}$ Tecnóloga Oftálmica do Laboratório de Eletrofisiologia Visual Clínica do Departamento de Oftalmologia e pósgraduanda em Ciências Visuais pela UNIFESP - São Paulo (SP) - Brasil.

${ }^{5}$ Mestre em Ciências Visuais e Tecnólogo Oftálmico do Laboratório de Eletrofisiologia Visual Clínica da UNIFESP - São Paulo (SP) - Brasil.

Endereço para correspondência: Solange Rios Salomão. Departamento de Oftalmologia Universidade Federal de São Paulo - UNIFESP - Rua Botucatu, 822 - São Paulo (SP) CEP 04023-062

E-mail: ssalomao@oftalmo.epm.br

Auxílio CAPES no 7230005-3

Recebido para publicação em 05.08 .2007

Última versão recebida em 18.02.2008

Aprovação em 07.03.2008

\section{INTRODUCTION}

Grating acuity is a visual task based on the resolution ability of the visual system which is widely used in non-verbal and preverbal patients (infants, toddlers, patients with developmental delay, patients with neurological impairment etc.). Grating acuity thresholds can be determined either by psychophysical techniques such as Teller acuity cards (TAC) or by electrophysiological procedures. Grating acuity development measured by TAC has been described previously in a large sample study ${ }^{(1)}$.

Pattern-reversal visually evoked potentials (VEP) can also be used to determine grating acuity thresholds. However it is a time consuming procedure with limited clinical usefulness. An alternative electrophysiologic technique to measure objectively grating acuity is the sweep-VEP procedure described by Norcia and Tyler ${ }^{(2)}$. A range of spatial frequencies can be swept in a 10-second presentation interval providing a fast and reliable grating acuity threshold. An additional advantage of this technique is the agreement between the grating acuity measured by sweep-VEP and optotype acuity ${ }^{(3)}$. Sweep-VEP grating acuity has been used in several pediatric eye disorders including strabismus ${ }^{(4-6)}$, children with developmental delay ${ }^{(4,7-8)}$, blepharoptosis ${ }^{(9)}$, innate metabolic errors ${ }^{(10)}$ and toxic visual disorders ${ }^{(11)}$. 
The sweep-VEP method has been used to describe agerelated visual development, mainly in the first year of life and under binocular testing conditions ${ }^{(2,12-17)}$. However, for a precise and reliable clinical diagnosis of reduced visual acuity and/ or amblyopia, the assessment of visual acuity requires monocular testing and interocular acuity difference age-related norm values.

The International Society for Clinical Electrophysiology of Vision (ISCEV) recommends that each Electrophysiology Laboratory should have its own normative database to compare with abnormal conditions and to provide precise diagnosis of visual pathways disorders. In that sense, it is very important to describe how grating acuity measured by sweepVEP behaves during the first years of life.

The aim of the present study was to determine monocular grating acuity development measured by sweep-VEP in healthy children in the first 36 months of life to provide a basis for age norms for visual acuity and interocular acuity differences measured by this technique.

\section{METHODS}

\section{Participants}

A group of 67 healthy full-term children, aging from 1 to 36 months of life underwent grating acuity measurement in the Clinical Electrophysiology of Vision Laboratory of the Department of Ophthalmology of the Federal University of São Paulo (UNIFESP), São Paulo, Brazil. Subjects were recruited by pediatric private practice and employees from the university whose children were in this age range. Exclusion criteria were: visual complaints, family history of eye disorders, abnormal perinatal event, congenital malformation or infection and eye problems noticed by the pediatrician and/or the ophthalmologist. Informed consent was obtained from parents before testing and the tenets of the Declaration of Helsinki were followed. This study protocol was approved by the Committee of Ethics in Research of the Federal University of São Paulo.

\section{Procedures}

\section{Ophthalmic examination}

A comprehensive ophthalmic examination including external eye examination, ocular motility assessment, biomicroscopy, cycloplegic refraction and fundus assessment with indirect binocular ophthalmoscopy was performed before grating acuity testing by a pediatric ophthalmologist (FE).

\section{Sweep-VEP acuity}

Monocular visual acuity testing was performed using the PowerDiva (digital infant vision assessment) sweep VEP system, developed by $\operatorname{Norcia}^{(18)}$. This system utilizes two interfacing MacIntosh G3 computers: the "host" computer selects the stimulus, establishes stimulus and trial parameters and analyzes the evoked response; the "video" computer controls the display monitor and shows the stimuli to the subject. The stimuli were phase-reversal sine-wave gratings presented on a 17.5 inches $(29 \times 38 \mathrm{~cm})$ high-resolution monochromatic video monitor (M20DCD4RE-Richardson Eletronics ${ }^{\circledR}$ ). Mean luminance $\left(140 \mathrm{~cd} / \mathrm{m}^{2}\right)$ was constant throughout the session. Responses were obtained from electroencephalogram electrodes (Grass Gold Disc Electrodes - E6GH) attached to the scalp with electrode cream and cotton pads. A headband (3M Coban SelfAdherent Wrap 1581) was used to keep the electrodes in place. The EEG was recorded from two bipolar placements $\left(\mathrm{O}_{1}\right.$ and $\left.\mathrm{O}_{2}\right)$, $2-3 \mathrm{~cm}$ to the left and right of a ground electrode placed $1 \mathrm{~cm}$ above the inion on the midline. A reference electrode was placed in the vertex. The potential differences were amplified (gain $=10,000 ;-3 \mathrm{db}$ cutoff at 1 and $100 \mathrm{~Hz}$ ).

Fixation was maintained during each trial with small toys presented hanging in front of the TV monitor and small music boxes to call the infant's attention. When the subject was alert and fixating the monitor (judged by the position of the image of the monitor centered in the subject's pupil), an observer pressed the mouse button and the EEG was recorded from the two channels and adaptively filtered (bandpass) in real time (sampling rate $=397 \mathrm{~Hz}$ ) to isolate the VEP. Amplitude and phase of the first and second harmonics of the stimulus frequency were calculated for each channel. The test was performed in a dark room so that the primary cues for accommodation were provided by the display.

Grating acuity was measured by sweeping spatial frequency at a fixed contrast $(80 \%) ; 10$ linearly-spaced spatial frequencies were presented, one per sec, starting at a low spatial frequency. The ranges of spatial frequencies and testing distances are shown in table 1. Patterns were temporally alternated in counterphase with a temporal modulation of $6.6 \mathrm{~Hz}$ for all tests. Three to 12 repetitions of the sweep were obtained and vector averaged. Grating acuity was estimated with an automated algorithm which performs a linear fit and extrapolation to zero amplitude for the final descending limb of the function relating VEP second harmonic amplitude to linear spatial frequency. A signal-to-noise ratio (SNR) at peak mean amplitude of 3:1 was required. In all cases, two thresholds (one for each channel) were obtained. The final acuity score was calculated in logMAR using the results of the better threshold channel with highest SNR. Sweep-VEP tests, including set-up and rest breaks, typically lasted 10 to 20 minutes, depending on the subject's age and cooperation.

\section{RESULTS}

Table 2 and figure 1 show age norms based on median and $95^{\text {th }}$ percentile for lower limit (normal lowest acuity for each age) obtained from 1-36 months of age. Mean values and their respective standard deviations are also shown for better description of the data. Mean sweep-VEP grating acuity ranged from $0.80 \log$ MAR (20/125 Snellen equivalent) in the first 


\begin{tabular}{|cccc|}
\hline & \multicolumn{2}{c|}{ Table 1. Testing distances and spatial frequency sweep in different age groups } \\
\hline Age (months) & Testing distance $(\mathbf{c m})$ & Spatial frequency at sweep start (cpd) & Spatial frequency at sweep end (cpd) \\
$1-3$ & 50 & 0.5 & 8 \\
$4-5$ & 80 & 1 & 15 \\
$6-11$ & 100 & 1 & 18 \\
$12-17$ & 100 & 2 & 25 \\
$18-24$ & 100 & 2 & 25 \\
$25-36$ & 150 & 2 & 28 \\
$\mathrm{cpd}=$ cycles/degree & & & \\
\hline
\end{tabular}

\begin{tabular}{|c|c|c|c|c|c|c|c|c|c|c|}
\hline $\begin{array}{l}\text { Age group } \\
\text { (months) }\end{array}$ & $\mathbf{N}$ & $\begin{array}{c}\text { Mean acuity } \\
\text { logMAR }\end{array}$ & $\begin{array}{l}\text { Snellen } \\
\text { equivalent }\end{array}$ & $\begin{array}{c}\text { SD } \\
\log M A R\end{array}$ & $\begin{array}{l}\text { Lower limit } \\
\text { mean+2SD }\end{array}$ & $\begin{array}{l}\text { Lower limit } \\
\text { Snellen } \\
\text { equivalent }\end{array}$ & $\begin{array}{l}\text { Median } \\
\text { log }\end{array}$ & $\begin{array}{l}\text { Median } \\
\text { Snellen } \\
\text { equivalent }\end{array}$ & $\begin{array}{c}\text { Lower limit } \\
\left(95^{\text {th }} P\right. \\
\text { logMAR) }\end{array}$ & $\begin{array}{c}\text { Lower limit } \\
\left(95^{\text {th }} P\right. \\
\text { Snellen })\end{array}$ \\
\hline 2 & 7 & 0.80 & $20 / 125$ & 0.10 & 1.00 & $20 / 200$ & 0.79 & 20/125 & 0.95 & $20 / 180$ \\
\hline 4 & 9 & 0.63 & $20 / 85$ & 0.09 & 0.81 & $20 / 130$ & 0.64 & $20 / 90$ & 0.73 & $20 / 110$ \\
\hline 6 & 8 & 0.47 & $20 / 60$ & 0.10 & 0.67 & $20 / 95$ & 0.43 & $20 / 55$ & 0.59 & $20 / 80$ \\
\hline 8 & 7 & 0.42 & $20 / 55$ & 0.08 & 0.58 & $20 / 75$ & 0.37 & $20 / 45$ & 0.53 & $20 / 70$ \\
\hline 12 & 8 & 0.33 & $20 / 45$ & 0.06 & 0.45 & $20 / 55$ & 0.33 & $20 / 45$ & 0.42 & $20 / 55$ \\
\hline 16 & 6 & 0.19 & $20 / 30$ & 0.02 & 0.23 & $20 / 35$ & 0.18 & $20 / 30$ & 0.22 & $20 / 35$ \\
\hline 22 & 7 & 0.13 & $20 / 25$ & 0.04 & 0.21 & $20 / 30$ & 0.14 & $20 / 30$ & 0.17 & $20 / 30$ \\
\hline 30 & 9 & 0.09 & $20 / 25$ & 0.04 & 0.17 & $20 / 30$ & 0.11 & $20 / 25$ & 0.15 & $20 / 30$ \\
\hline 36 & 6 & 0.06 & $20 / 20$ & 0.04 & 0.14 & $20 / 30$ & 0.05 & $20 / 20$ & 0.12 & $20 / 25$ \\
\hline
\end{tabular}

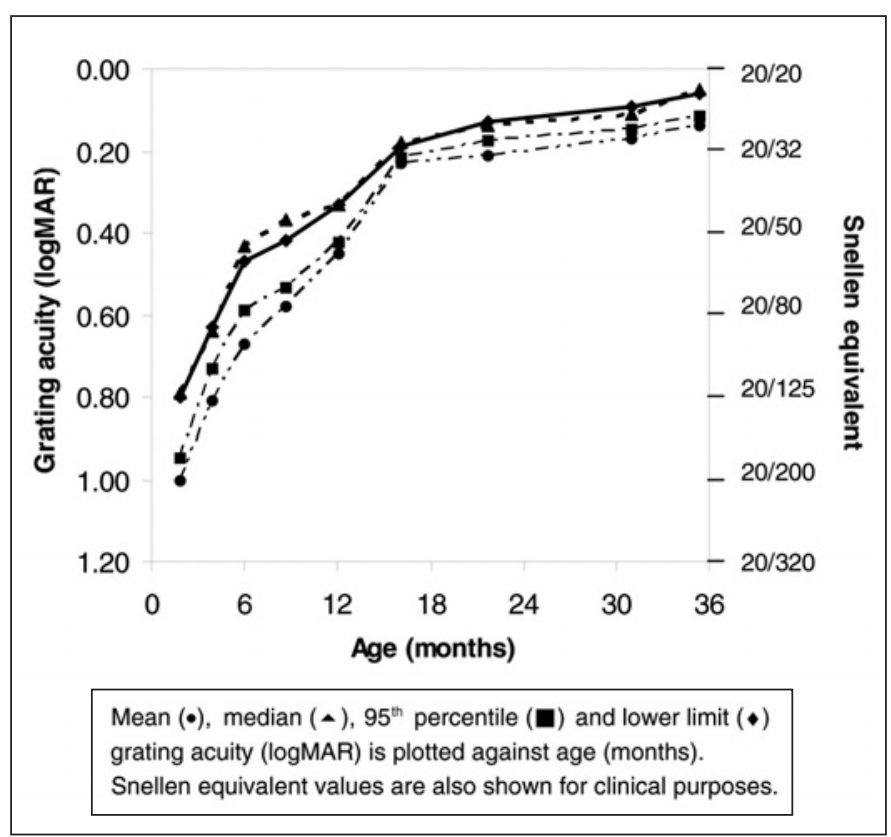

Figure 1 - Grating acuity development in the first 36 months of age measured by sweep-VEP

month of life to $0.06 \operatorname{logMAR}(20 / 20$ Snellen equivalent) at 36 months of age. Lower normal limits $\left(95^{\text {th }}\right.$ percentile) ranged from $0.95 \log$ MAR (20/180) to $0.12 \log$ MAR (20/25) with approximately 3 octaves progression in the first 36 months of age. There is a linear progression between grating acuity $(\log M A R)$ and age (log weeks) in the first 36 months of age (Figure 2).

Interocular acuity difference (IAD) was calculated by absolute subtraction of grating acuity from each eye (logMAR). Calculations were not performed for two children (aged one month and 12 month respectively) who were able to cooperate but for one eye at alternate monocular testing. These results are shown in table 3. Median IAD ranged from 0.01 to $0.03 \log$ MAR and the $95^{\text {th }}$ percentile ranged from 0.03 to 0.09 .

\section{DISCUSSION}

Grating acuity development measured by sweep-VEP and presented in this study confirms and extends previous findings regarding the normal development of spatial vision. Optical $^{(19-20)}$, neural ${ }^{(19-21)}$ and anatomic ${ }^{(19,21)}$ development of the visual system progress along the first years of life. Because of poor acuity, newborns can see only big objects. A probable major factor to explain this limited spatial resolution is the retinal immaturity ${ }^{(22)}$. Cones in their foveas are scarcely distributed, showing short, large and misaligned external segments. In contrast, segments of the adult foveal cones are densely distributed, well developed and aligned ${ }^{(19)}$. Another important factor is the development of visual cortex which depends on appropriate visual stimuli, mainly during the first 5-7 years of age, when the synaptic connections are being established $^{(19,23)}$. 


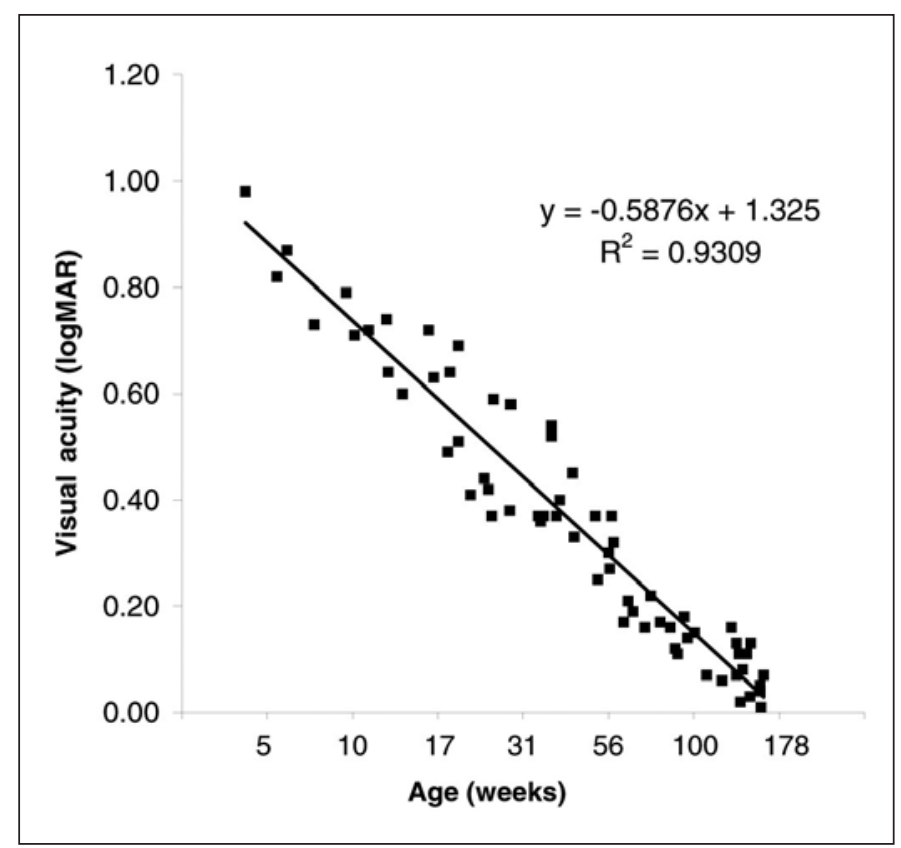

Figure 2 - Individual grating acuity scores (logMAR) and their respective age $(\mathrm{log})$ in months from 67 healthy full-term children. A linear regression line shows good correlation between log acuity and log age.

Table 3. Mean and median interocular grating acuity difference (IAD) measured in IogMAR with their respectives standard deviations (SD) and $95^{\text {th }}$ percentiles $\left(95^{\text {th }} \mathrm{P}\right)$ obtained from $65^{*}$ healthy full-term children and its distribution according to age groups

\begin{tabular}{cccccr|}
$\begin{array}{c}\text { Age group } \\
\text { (months) }\end{array}$ & $\begin{array}{c}\text { IAD } \\
\text { mean }\end{array}$ & $\begin{array}{c}\text { IAD } \\
\text { SD }\end{array}$ & $\begin{array}{c}\text { IAD } \\
\text { mean+2SD }\end{array}$ & $\begin{array}{c}\text { IAD } \\
\text { median }\end{array}$ & $\begin{array}{r}\text { IAD } \\
9^{\text {th }} \mathbf{P}\end{array}$ \\
2 & 0.03 & 0.02 & 0.07 & 0.02 & 0.06 \\
4 & 0.02 & 0.01 & 0.04 & 0.02 & 0.04 \\
6 & 0.01 & 0.01 & 0.03 & 0.01 & 0.03 \\
8 & 0.02 & 0.03 & 0.08 & 0.01 & 0.07 \\
12 & 0.03 & 0.03 & 0.09 & 0.03 & 0.08 \\
16 & 0.04 & 0.03 & 0.10 & 0.03 & 0.09 \\
22 & 0.03 & 0.02 & 0.07 & 0.02 & 0.05 \\
30 & 0.02 & 0.02 & 0.06 & 0.02 & 0.05 \\
36 & 0.03 & 0.02 & 0.07 & 0.02 & 0.05 \\
${ }^{*}=$ in two subjects it was impossible to obtain monocular visual acuity measu- \\
rements in both eyes avoiding the calculation of IAD
\end{tabular}

In the examined group of children, a marked improvement in grating acuity occurred between ages 1 and 6 months with a difference of 2 octaves with grating acuity improving from $20 / 235$ to $20 / 60$, followed by approximately a third of octave in the subsequent tested ages and a plateau between ages 24 months and 36 months. These findings are in line with previous reports of grating acuity measured by the same technique in the first 60 weeks of life $\mathrm{e}^{(2,13-15,24-25)}$.

Another important methodological difference among previous reports and our study is the monocular grating acuity testing. All previous reports are based on binocular measurements, to improve cooperation and attention during sweep-VEP recording. However, it is not possible to obtain interocular acuity difference normative data unless monocular testing is performed. Our results show that interocular acuity differences $>0.1 \log$ MAR are significant and should be considered for amblyopia diagnosis and patching monitoring. In spite of some variability across ages, we believe that 0.10 should be considered the largest acceptable IAD for clinical purposes.

Grating acuity age norms provided in this study allow comparison of this visual function in the first 36 months of age along with interocular acuity differences norms. We believe that these parameters will be useful in the diagnosis of visual acuity deficit and amblyopia in pediatric visual disorders.

\section{CONCLUSIONS}

Grating acuity measured by sweep-VEP was obtained from healthy full-term children in the first 36 months of age. Age norms for this visual function along with interocular acuity differences were determined and should be incorporated in clinical practice for precise diagnosis of visual status in infants and preverbal children.

\section{RESUMO}

Objetivos: Propor valores normativos de acuidade visual de grades e sua respectiva diferença interocular medidas pelo potencial visual evocado de varredura nos primeiros três anos de vida. Métodos: Foram avaliadas 67 crianças sadias, sem doenças oculares, que tiveram a acuidade visual medida pelos potenciais evocados visuais de varredura. Resultados: A acuidade visual média variou de $0,80 \log M A R$ (equivalente de Snellen de 20/125) no primeiro mês de vida a $0,06 \log M A R$ (equivalente de Snellen de 20/20) aos 36 meses. Os limites normais inferiores (percentil 95\%) variaram de 0,95 logMAR (20/180) a 0,12 logMAR (20/25) com progressão de aproximadamente 3 oitavas nos primeiros 36 meses de vida. A diferença interocular máxima aceitável foi de 0,10 logMAR. Conclusões: Os valores normativos de acuidade visual e de diferença interocular de acuidade foram obtidos pela técnica do potencial visual evocado de varredura. Propõe-se sua adoção na prática clínica para diagnóstico preciso do estado visual de bebês e de crianças pré-verbais.

Descritores: Potenciais evocados visuais; Acuidade visual; Testes visuais/normas; Valor preditivo dos testes; Valores de referência

\section{REFERENCES}

1. Salomão SR, Ventura DF. Large sample population age norms for visual acuities obtained with Vistech-Teller Acuity Cards. Invest Ophthalmol Vis Sci. 1995;36(3):657-70.

2. Norcia AM, Tyler CW Spatial frequency sweep VEP: visual acuity during the first year of life. Vision Res. 1985;25(10)1399-408. 
3. Arai M, Katsumi O, Paranhos FR, Lopes De Faria JM, Hirose T. Comparison of Snellen acuity and objective assessment using the spatial frequency sweep PVER. Graefes Arch Clin Exp Ophthalmol. 1997;235(7):442-7.

4. Gottlob I, Fendick MG, Guo S, Zubcov AA, Odom JV, Reinecke RD. Visual acuity measurements by swept spatial frequency visual-evoked-cortical potentials (VECPs): clinical application in children with various visual disorders. J Pediatr Ophthalmol Strabismus. 1990;27(1):40-7.

5. Jampolsky A, Norcia AM, Hamer RD. Preoperative alternate occlusion decreases motion processing abnormalities in infantile esotropia. J Pediatr Ophthalmol Strabismus. 1994;31(1):6-17.

6. Norcia AM, Garcia H, Humphry R, Holmes A, Hamer RD, Orel-Bixler D. Anomalous motion VEPs in infants and in infantile esotropia. Invest Ophthalmol Vis Sci. 1991;32(2):436-9.

7. Costa MF. Acuidade visual de resolução de grades em crianças com paralisia cerebral do tipo espástico pelo método de potenciais evocados de varredura [tese]. São Paulo: Universidade de São Paulo; 2001.

8. Good WV. Development of a quantitative method to measure vision in children with chronic cortical visual impairment. Trans Am Ophthalmol Soc. 2001; 99:253-69.

9. Cibis GW, Fitzgerald KM. Amblyopia in unilateral congenital ptosis: early detection by sweep visual evoked potential. Graefes Arch Clin Exp Ophthalmol. 1995;233(10):605-9.

10. Birch EE, Hoffman DR, Uauy R, Birch DG, Prestidge C. Visual acuity and the essentiality of docosahexaenoic acid and arachidonic acid in the diet of term infants. Pediatr Res. 1998;44(2):201-9.

11. Till C, Rovet JF, Koren G, Westall CA. Assessment of visual functions following prenatal exposure to organic solvents. Neurotoxicology. 2003;24(4-5): 725-31.

12. Hamer RD, Norcia AM, Tyler CW, Hsu-Winges C. The development of monocular and binocular VEP acuity. Vision Res. 1989;29(4):397-408.

13. Sokol S, Moskowitz A, McCormack G. Infant VEP and preferential looking acuity measured with phase alternating gratings. Invest Ophthalmol Vis Sci. 1992;33(11):3156-61.
14. Allen D, Tyler CW, Norcia AM. Development of grating acuity and contrast sensitivity in the central and peripheral visual field of the human infant. Vision Res. 1996;36(13):1945-53.

15. Birch EE, Hoffman DR, Uauy R, Birch DG, Prestidge C. Visual acuity and the essentiality of docosahexaenoic acid and arachidonic acid in the diet of term infants. Pediatr Res. 1998;44(2):201-9.

16. Lauritzen L, Jorgensen MH, Michaelsen KF. Test-retest reliability of swept visual evoked potential measurements of infant visual acuity and contrast sensitivity. Pediatr Res. 2004;55(4):701-8.

17. Birch EE, Castañeda YS, Wheaton DH, Birch DG, Uauy RD, Hoffman DR Visual maturation of term infants fed long-chain polyunsaturated fatty acidsupplemented or control formula for 12 mo. Am J Clin Nutr. 2005;81(4): 871-9.

18. Norcia AM. PowerDiva manual. San Francisco: Smith-Kettlewell Eye Research Institute; 1999.

19. Maurer D, Lewis TL.Visual acuity: the role of visual input in inducing postnatal change. Clin Neurosci Res. 2001;1(4):239-47.

20. Harwerth RS, Smith EL $3^{\text {rd }}$, Duncan GC, Crawford ML, Von Noorden GK Multiple sensitive periods in the development of the primate visual system. Science. 1986;232(4747):235-8

21. Berardi N, Pizzorusso T, Ratto GM, Maffei L. Molecular basis of plasticity in the visual córtex. Trends Neurosci. 2003;26(7):369-78.

22. Berezovsky A, Moraes NS, Nusinowitz S, Salomão SR. Standard full-field electroretinography in healthy preterm infants. Doc Ophthalmol. 2003;107(3):243-9.

23. Horton J, Stryker MP. Amblyopia induced by anisometropia without shrinkage of ocular dominance columns in striate cortex. Proc Natl Acad Sci USA. 1993;90(12):5494-8.

24. Norcia AM, Tyler CW, Hamer RD. Development of contrast sensitivity in the human infant. Vision Res. 1990;30(10):1475-86.

25. Auestad N, Montalto MB, Hall RT, Fitzgerald KM, Wheeler RE, Connor WE, et al. Visual acuity, erythrocyte fatty acid composition, and growth in term infants fed formulas with long chain polyunsaturated fatty acids for one year. Ross Pediatric Lipid Study. Pediatr Res. 1997;41(1):1-10. 